\title{
An uncommon cause of a common disorder: Questions
}

\section{Sare Gülfem Özlü ${ }^{1}$ (D) - Sonay İncesoy Özdemir ${ }^{1,2} \cdot$ Dilek Kılıc $^{3} \cdot$ Ayşegül Neşe Citak Kurt $^{4}$}

Received: 18 May 2020 / Accepted: 3 June 2020 / Published online: 17 August 2020

(C) IPNA 2020

\section{Case summary}

A 7-year-old girl who had been followed up with cerebral palsy and epilepsy was consulted to our pediatric nephrology outpatient clinic because of incidentally detected hyponatremia on routine follow-up. She had birth-adjusted cerebral palsy and received various antiepileptics since the newborn period.

She had been on treatment with valproic acid and clonazepam for 1 year and 3 months prior to her referral and the dosage of valproic acid had been increased to $40 \mathrm{mg} / \mathrm{kg} /$ daily because of short-lasting intractable seizures.

At admission, her vital signs were normal; she had no signs of dehydration or hypovolemia. Neurological examination revealed increased deep tendon reflexes and Babinski reflex. Other systemic examination findings were normal.

Laboratory investigations were as follows: glucose $94 \mathrm{mg} /$ dl (74-106), creatinine $0.27 \mathrm{mg} / \mathrm{dl}(0.3-0.7)$, urea $17 \mathrm{mg} / \mathrm{dl}$ (11-38), sodium $129 \mathrm{mEq} / \mathrm{L}$ (135-145), potassium $4.83 \mathrm{mEq} /$ L (4.1-5.3), calcium $9.21 \mathrm{mg} / \mathrm{dl}$ (8.5-10), phosphorus $4.5 \mathrm{mg} /$ dl (4.5-5.5), chloride $99 \mathrm{mEq} / \mathrm{L}$ (98-107), magnesium 1.88 $\mathrm{mg} / \mathrm{dl}$ (1.5-2.3), aspartate aminotransferase 35.7 IU/L (15$60)$, alanin aminotransferase $10.5 \mathrm{IU} / \mathrm{L}(0-35)$, and uric acid $2 \mathrm{mg} / \mathrm{dl}(2.6-6)$. Thyroid function tests were normal. Blood

The answers to these questions can be found at https://doi.org/10.1007/ s00467-020-04649-6.

Sare Gülfem Özlü

saredr@gmail.com

1 Department of Pediatric Nephrology, Ankara Yıldırım Beyazıt University, Faculty of Medicine, Üniversiteler Mahallesi, Çankaya, Ankara, Turkey

2 Department of Pediatric Oncology, Ankara Y1ldırım Beyazit University, Faculty of Medicine, Ankara, Turkey

3 Department of Radiology, Ankara Yıldırım Beyazıt University, Yenimahalle Training and Research Hospital, Ankara, Turkey

4 Department of Pediatric Neurology, Ankara Yıldırım Beyazit University, Faculty of Medicine, Ankara, Turkey gas analysis revealed a $\mathrm{pH}$ of $7.44, \mathrm{HCO}^{3}$ of 22.9 , and $\mathrm{pCO}$ of 27.3. Serum level of valproic acid was $142 \mathrm{micgr} / \mathrm{ml}$ (theraupetic range 50-100 $\mathrm{micgr} / \mathrm{ml}$ ). Urine sodium was 41 $\mathrm{mEq} / \mathrm{L}$, potassium was $15 \mathrm{mEq} / \mathrm{L}$, and density was 1025 ; urine microscopic examination was normal. Plasma osmolality was $269 \mathrm{mOsm} / \mathrm{kg}$ and urine osmolality was 280 $\mathrm{mOsm} / \mathrm{kg}$. Ultrasonographic examination of kidneys and the urinary tract was normal. Cranial computerized tomography was normal except for chronic alterations due to perinatal asphyxia.

\section{Questions}

1 What is your diagnosis for this patient?

2 What is the underlying etiology of this disorder?

3 What is the best management strategy for this patient?

\section{Compliance with ethical standards}

Conflict of interest The authors declare that they have no conflict of interest.

Publisher's note Springer Nature remains neutral with regard to jurisdictional claims in published maps and institutional affiliations. 